\title{
A Review Study on the Adoption of Cloud Computing for Higher Education in Kurdistan Region - Iraq
}

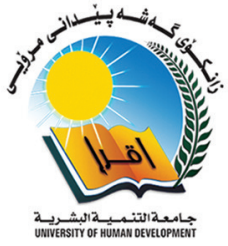

\author{
Abbas M. Ahmed', Osamah Waleed Allawi² \\ ${ }^{1}$ Department of Business Administration, Sulaimani Polytechnic University, Sulaimani, Iraq, ${ }^{2}$ Department of Computer \\ Technology, Al-Hikma University College, Baghdad, Iraq
}

\begin{abstract}
A B S T R A C T
Cloud computing $(\mathrm{CC})$ is considering as a popular computing model in the Western World. It is still not well understood by much higher education (HE) institutions in the developing world. CC will positively affect its consumers in executing their role in an economical way. It can be done using applications provided by the cloud specialist organizations. This study aims to evaluate the factors that influence the adoption of CC for HE within the Kurdistan Region in Iraq. The study was performed utilizing a non-experimental study exploratory research design. This exploratory study included an essential investigation into secondary data. The study development and modeling of secondary data to highlight the final results of the research. Through reviewing the literature of the existing frameworks in CC adoption, it is showed that there are limited institutions developed over the latest years. Moreover, HE in Kurdistan Region needs continued attention to get government support and redesign the educational system to cover all the core aspects in a better way. Here, at any time, there is a need to access the applications, software and hardware, platform, and infrastructure; the most required is to have the internet service.
\end{abstract}

Index Terms: Cloud Computing Adoption, Higher Education, Education Systems, Kurdistan Region - Iraq, Electronic Learning

\section{INTRODUCTION}

Higher education (HE) scenery all over the world is in a continuous state of influx and development, mainly as a result of essential challenges stemming from efforts in adopting new and growing technologies. Using technology will improve $\mathrm{HE}$ which will result in providing high-quality education and prepare the students to face the challenges of the $21^{\text {st }}$ century [1]. Kurdistan regional government (KRG)

\begin{tabular}{|l|l|}
\hline \multicolumn{2}{|c|}{ Access this article online } \\
\begin{tabular}{|l|l|}
\hline DOI:10.21928/uhdjst.v4n1y2020.pp59-70 & E-ISSN: 2521-4217 \\
P-ISSN: 2521-4209
\end{tabular} \\
\hline $\begin{array}{l}\text { Copyright @ 2020 Ahmed and Allawi. This is an open access article } \\
\text { distributed under the Creative Commons Attribution Non-Commercial } \\
\text { No Derivatives License 4.0 (CC BY-NC-ND 4.0) }\end{array}$ \\
\hline
\end{tabular}

could be a developing area in several faces, HE has been developed in this region, there are 28 universities, according to the Kurdistan ministry of HE (MHE) [2].

Cloud computing (CC) is a collection or group of hardware and software to human beings through the internet. CC provides many advantages such as steady, rapid, sample, suitability, and simultaneous accessibility of belongings at low cost in comparison with other techniques through the internet to the users. Resources can be requested by the consumers depending on their requirements. These requirements can be storing data, communication, data processing, and calculation cycles needed for their applications [3].

Each cloud has its own users. The services of the cloud can be accessed by the user to retain the increasing daily and safety systems in the CC environments. The specific role of

Corresponding author's e-mail: Abbas M. Ahmed, Department of Business Administration, Sulaimani Polytechnic University, Sulaimani, Iraq E-mail: abbas.ahmed@spu.edu.iq 
the CC is that it can be used through exploiting the internet and the PCs in the data centers. The role of CC is important in the academic and industrial domain [4].

As mentioned above, HE is in continuous development according to the requirements of modern life. It is so-known that effectively using technology in $\mathrm{HE}$ is one of the key factors for providing high-quality education. The cost is the main reason for the slow adopting of new technologies in HE. The local societies and the whole world transformation demand huge funding and investment. These factors are difficult to come at the times of deep economic downturn and depleted budget reserves whether budgets of the government or the private institutions. The financial support provided to HE institutes has sharply decreased in times of recession, leading to financial difficulties in $\mathrm{HE}$ institutions (HEIs). To address their fiscal deficit, HE institutes have recourse to a variety of cost-cutting measures, including important cuts to information technology (IT) budgets [5].

However, in this paper, many studies have been reviewed, discussed, and critically analyzed to providing a solid literature review for future research. In addition, a wide range of case studies from past up to date is presented for a better understanding of the theory related to applying the CC in HEs. Articles, journals, books, and previous works had been listed in the following tasks.

Many well-established reviews and survey articles on applying CC in HE available in the literature such as Amron et al., Qadri and Qadri, Rawajbeh et al., Al-Shqeerat et al. [6]-[9], Singh and Baheti [10]. Amron et al. [6] reviewed three sectors in applying CC which will be the health-care sector, higher learning organization, and the public field. In the manner, Qadri and Quadri [7] reviewed numerous CC applications with emphases on the security aspect. In the work of $\mathrm{Al}$ Rawajbeh et al. [8], they clarify the roadmap of the successful adoption of CC in high education institutions. In the work of Al-Shqeerat et al. [9] provided baseline recommendations to avoid security risks efficiently when adopting CC in HE. Whereas, in the work of Singh and Baheti [10], they discussed the limitations and problems of the traditional education methods in additional education based on CC. Fig. 1 shows the number of reviewed and discussed articles in this work based on the years, note, and $*$ represents the number of review articles.

\subsection{Paraphrase}

A total of 39 research articles and five review articles are covered in this work. The review emphasizes the CC

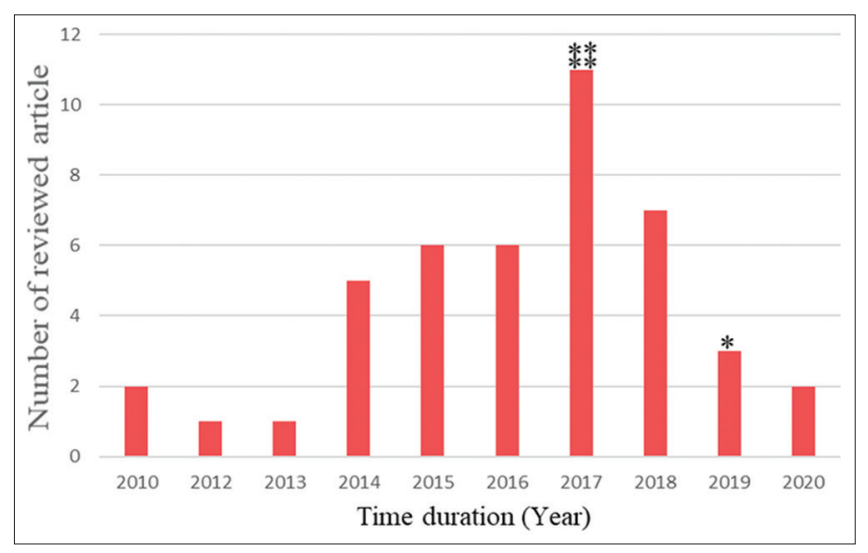

Fig. 1. Number of the reviewed article.

service and its applications in HEs. Furthermore, our work distinguishes itself from the previous by it is studying the possibility of applying the CC service in HE of the Kurdistan Region - Iraq. This review approach allows us to improve the scope and shape the direction of HE based on IT.

This paper segmented into four parts starting with the section of introduction which describes the CC service and it is an application in education. Furthermore, the related work has been discussed in section 2. Furthermore, in section 3 an overview of the CC service and it is an application in HEs. Finally, section 4 presents the conclusion of this paper.

\section{RELATED WORK}

A literature search is a pre-requisite for reviewing the literature on any subject, in general, this is done by scanning some prominent journals and conferences exclusively dedicated to the subject, concentrating on limited outlets cannot be considered as enough justification for a literature review on CC in HE as this is a recent phenomenon [2]. This is the reason why the publication channels till now are largely scattered for most of the concurrent phenomena, information science researchers and scholars are using online databases as their first literature collecting strategy.

The CC aspect is useful when was implemented for some universities such as California University (UC). They found that implementation of $\mathrm{CC}$ enhanced the development. Also, the implementation of software as a service (SaaS) applications CC which made the difference in increasing the advantages to students, such as make the exams online, have access to their exercises and solve it and resend it again, projects submitted by students, feedback facility between students and teachers. It also provides the facility of 
communication between students, using the applications by the students as well as the teachers without installing those applications on their computers and without store-related application files. Furthermore, the ability to access any computer from anywhere and at any time when the internet service is available can be possible too. The core concern related to applying the $\mathrm{CC}$ in $\mathrm{HE}$ fields is security issues. At the same time, this does not mean that there are some other obstacles related to trusting, trust, and assurance [11].

The educational cloud represents one of the most interesting applications of CC. To meet their most requirements, the private educational institutes are betaking toward using IT technology. The increasing dependence on IT requires the availability of the internet to students and institutes [12].

One of the main problems in Iraq is the lack of network infrastructure. Abdusalam et al. [13] mentioned useful information on the challenges and current status of the backbone infrastructure and internet in the KRG which provided by private companies from several countries, namely, Iraq, Iran, Turkey, and the others [14]. Universities in KRG are willing to use modern techniques in the education process and teaching methodologies. The cornerstone of the modern education system is using Information and Communication Technologies (ICT). Unfortunately, the MHE in Kurdistan suffers from a lack of ICT infrastructure in its governorates [15], and clearly; this means that establishing ICT infrastructure for universities requires extensive time, investment, and efforts. Furthermore, some researchers in Masud et al. [1] aimed to improve an instrument to investigate the factors of CC service based on the theory of planned behavior.

Some researchers focused on the materiality of each dimension and weight of each sub-dimension such as Thabit and Harjan [16]. The researchers checked the opinions of the Avicenna Center and Gihan University academic staff with 40 questionnaires. The questionnaire also contains some points related to developing the activities of the Avicenna center in Erbil. Thabit and Harjan [16] concludes that the e-learning Avicenna Center has to develop a new department of training the staff to deal with e-learning centers and improves the university students' skills to create a new generation compatible with e-learning technologies.

In addition, Riaz and Muhammad [17] proposed that the limitation of the education requirements in growing countries like Pakistan can be solved through the adoption of the CC. This action can guarantee that all the software resources and ICT based possessions can be shared among learners.
All the data confidentiality and integrity processed by the institutes can be defined as the data security according to many studies. This risk can be reduced through a model that complies with all the academic and administrative staffs' requirements and at the same time, all the users' devices are separated to reduce data theft chance. This action was done by controlling the data storage of each user device through different port from other users' data storage [18].

Amron et al. [6] reviewed three sectors in applying CC which will be the health-care sector, higher learning organization, and the public field. Five key factors completely outclassed all three sectors; technology preparedness, human readiness, organization assistance, environment, and security, as well as privacy. Factors of connection and feedback and access to the internet hereditary factors pertinent to the HE community, generally the study is motivated by curiosity about the dependability of CC to become the leader in information storage technology. Although several studies found the actual CC brings much more benefits than disadvantages, the particular negative effects of the applied CC should become also being noted especially in the aspect associated with safety and data personal privacy factors [6].

The study by Qadri and Quadri [7] has assessed the behavioral intention of the students of Iraq, being in its infancy in terms of internet adoption; thus, going through the transformation of traditional modes of learning into e-learning modes. The study has employed the modified form of "technology acceptance model" (TAM) model to assess the attitudinal behavior of the students of Iraqi HE toward the use of learning management system as the educational platform, the study has led to the conclusion that there exists a significant association between the variables under consideration. The standings of Iraqi HE are noted to be significantly improved with respect to the past statistics. Besides, the study also affirms the credibility of the TAM model in facilitating the assessment criteria for diverse technological deployments.

CC has considerable standing in the HEIs worldwide and locally. As well as in Saudi Arabia, typically the IT market is considered such as the largest sector in the Gulf area. The Saudi government offers allocated huge finance to improve the academic environment with the very best technological facilities. On the other hand, there are unique start-up universities in Saudi Arabia that absence e-learning tools in comparison to the elderly universities in SA, Saudi universities even now slowly seek to embrace CC in the HE atmosphere for distance studying and e-learning, while CC has been 
broadly used in universities within different countries to provide higher quality services to be able to $\mathrm{HE}$ and also CC enables HEIs to deal with the needs regarding software and hardware modifications rapidly at lower expenses. Therefore, the adoption involving CC into HE encourages students' academic level in addition to efficiency. The research came to the conclusion that there is a good urgent need to produce a new web software based on CC as well as cover some of the holes in existing web applications [8].

CC represents a great opportunity for universities so that you can take advantage of the actual enormous benefits involving cloud services and also resources in the educative process. However, the cloud end users remain concerned regarding security issues that symbolize the major obstacle which may prohibit the usage of CC on a large scale. Typically, the limitations of cloud support models were investigated in addition to challenges as well as risks threaten cloud processing. The study demonstrates that the stakeholders are usually not familiar with feasible security risks or operations used to protect data as well as a cloud application. Furthermore, this indicates that the many serious attacks may threaten cloud networks usually are denial of service and also phishing attacks [9].

The teaching materials may be made available through the cloud service workers to educate the customer on the available risk operations issues as it pertains to cloud usage. This shows how crucial it will be for educators who usually are cloud service users to be able to understand how to manage all their information used in often the cloud. To the students, this enhances their participation in studies, increases all their enthusiasm and motivation, therefore the time at that they study is raises while the cost is actually reduced. The students obtain limitless access to net-based teaching-learning sources needing little or absolutely no effort from the teacher. Studying is gradually made electronic as educational institutions transfer their resources, students info system, learning management techniques, knowledge management techniques to the cloud, with that, students are capable to access the needed sources from anywhere in a versatile way [19].

The goal of Sultana et al. [20] study is to determine the factors that will certainly influence CC adopting in university associated with Dhaka of Bangladesh. In this research, some significant factors possess been derived from information collection and data analysis in different functions of this university. The absence of proper infrastructure, services availability, and effectiveness in education are observed most important. Some other factors are resource require, cloud control ability as well as lack of training of employees. An educational institution may focus on these elements to increase the utilization of CC technologies to provide studying to the student. Singh and Baheti [10] were conducted their study to overcome the limitations of traditional education and learning system, CC solutions tend to be very useful for academic institutions especially with regard to HE institutes. Along with the involvement associated with CC in learning system, students can obtain access to various sources (i.e., textbooks, magazines video lectures, demonstrative video, and lab facilities) which are not achievable in traditional education and learning system. Teachers can assess students in a much better way; researchers can obtain all the facilities as well as infrastructures related to all their research field. Definitely, not only teachers and learners but administrators should also opt for equipment for administration purposes. Inside overall CC has different services that might be included in the actual traditional education and learning system.

A study conducted by Başaran and Hama [21] to investigate university faculty members' views toward the adoption of $\mathrm{CC}$ in HE. The current status of the faculty on CC usage in education and regional differences was discussed. The data were collected through an adopted questionnaire based on these frameworks and demographic information was answered by 300 faculty members from the northern parts of Cyprus and Iraq. The results showed that faculty members agreed mostly on the opportunities followed by an awareness of potential threats and weaknesses and finally they accept the strengths of adopting CC in education. The study brought to light on the comprehension of faculty members' views from comparative and integrated framework perspectives. In general sense, faculty members from the north part of Iraq seem to be slightly more optimistic about the adoption of CC in educational settings. This might result from either they less frequently use CC services as compared to faculty members from the north part of Cyprus who are younger in mean age and can be considered as being more capable consumers of cuttingedge technologies like cloud. Interestingly, both parties are aware of the problems which could be resulted from adopting such innovation.

With the number of works of literature reviewed above, it shows that a number of studies have been conducted on the adoption of CC at HE in Kurdistan. These studies are carried out in different environments, countries, and industries. 
These studies showed that the CC is constantly evolving, and it became necessary for the different processes and activities within $\mathrm{HE}$ universities, and this requires the universities to apply it and use it. Despite the importance of CC usage and its role in activating the learning in Iraq to enhance education, there was a lack of researches and studies on the factors that affect the adoption of CC in Iraqi universities. As a result, there is a knowledge gap. This study aims to fill that gap. However, the analysis of the related work is shown in Table 1.

Based on the above discussion, it is observed that most of the studies emphases on the readiness factors of technological, HE, cost, educational, information security and cultural, as shown in Table 2 below:

\section{TABLE 1: The analysis and comparison of the related work.}

\begin{tabular}{|c|c|c|c|c|c|}
\hline Ref. & $\begin{array}{l}\text { Type of } \\
\text { service }\end{array}$ & Country & $\begin{array}{l}\text { Employment } \\
\text { place }\end{array}$ & Advantage & Disadvantage \\
\hline Kadhim [11] & $\begin{array}{l}\text { Cloud } \\
\text { computing }\end{array}$ & Iraq & $\begin{array}{l}\text { Basic } \\
\text { education }\end{array}$ & $\begin{array}{l}\text { It can improve the educational sector } \\
\text { It is suggesting the applying of decision- } \\
\text { making a feature in education } \\
\text { Internalize storage for confidential work }\end{array}$ & $\begin{array}{l}\text { Limited by geographical } \\
\text { scaling }\end{array}$ \\
\hline $\begin{array}{l}\text { Hashim } \\
\text { et al. [12] }\end{array}$ & $\begin{array}{l}\text { Cloud } \\
\text { computing }\end{array}$ & North Iraq & $\begin{array}{l}\text { Higher } \\
\text { education }\end{array}$ & $\begin{array}{l}\text { It gives the students an open and flexible } \\
\text { environment by applying the VCL in } \\
\text { Bayan University }\end{array}$ & $\begin{array}{l}\text { The proposed system does } \\
\text { not test yet } \\
\text { The study is limited only on } \\
\text { the Bayan University }\end{array}$ \\
\hline $\begin{array}{l}\text { Abdusalam } \\
\text { et al. [13] }\end{array}$ & $\begin{array}{l}\text { Cloud } \\
\text { computing }\end{array}$ & North Iraq & $\begin{array}{l}\text { Governments } \\
\text { Organization }\end{array}$ & $\begin{array}{l}\text { It assists in locating missteps in the } \\
\text { implementation stage } \\
\text { It is focused on the information security } \\
\text { aspect }\end{array}$ & $\begin{array}{l}\text { The study is limited on only } \\
\text { three status which are Dhok, } \\
\text { Erbil and Sulaymaniyah }\end{array}$ \\
\hline $\begin{array}{l}\text { Al-Hashimi } \\
\text { et al. [14] }\end{array}$ & $\begin{array}{l}\text { Cloud } \\
\text { computing }\end{array}$ & North Iraq & $\begin{array}{l}\text { Higher } \\
\text { education }\end{array}$ & $\begin{array}{l}\text { The possibility of applying the Cloud } \\
\text { computing services in the North Iraq } \\
\text { Universities } \\
\text { Operations have been proposed for } \\
\text { budget reductions }\end{array}$ & $\begin{array}{l}\text { limited by geographical } \\
\text { scaling }\end{array}$ \\
\hline $\begin{array}{l}\text { Asadi et al. } \\
\text { [22] }\end{array}$ & $\begin{array}{l}\text { Cloud } \\
\text { computing }\end{array}$ & General & $\begin{array}{l}\text { Higher } \\
\text { education }\end{array}$ & $\begin{array}{l}\text { demonstrated validity, reliability, simplicity, } \\
\text { and functionality of the } f \text { the Theory of } \\
\text { Planned Behavior - Cloud Computing } \\
\text { Services use Questionnaire TPB - CCSQ }\end{array}$ & $\begin{array}{l}\text { The proposed system } \\
\text { is tested only in higher } \\
\text { education }\end{array}$ \\
\hline $\begin{array}{l}\text { Thabit and } \\
\text { Harjan [16] }\end{array}$ & $\begin{array}{l}\text { Electronic } \\
\text { learning }\end{array}$ & North Iraq & $\begin{array}{l}\text { Higher } \\
\text { education }\end{array}$ & $\begin{array}{l}\text { Spread the culture of applying the E. } \\
\text { Learning in Avicenna Center of Erbil } \\
\text { Develop a new department of training the } \\
\text { staff to deal with e-learning centers }\end{array}$ & $\begin{array}{l}\text { The study focused only on } \\
\text { the Avicenna Center of Erbil }\end{array}$ \\
\hline $\begin{array}{l}\text { Riaz and } \\
\text { Muhammad } \\
{[17]}\end{array}$ & $\begin{array}{l}\text { Cloud } \\
\text { computing }\end{array}$ & Pakistan & $\begin{array}{l}\text { Higher } \\
\text { education }\end{array}$ & $\begin{array}{l}\text { It presents the usability evaluation of } \\
\text { public cloud applications across three } \\
\text { universities in Pakistan from stakeholders' } \\
\text { perspective, i.e., (teachers and students) }\end{array}$ & $\begin{array}{l}\text { They did not take into } \\
\text { consideration the applying of } \\
\text { Google sites to find out the } \\
\text { effects of public cloud } \\
\text { application in the education } \\
\text { sector }\end{array}$ \\
\hline $\begin{array}{l}\text { Sultana et al. } \\
{[20]}\end{array}$ & $\begin{array}{l}\text { Cloud } \\
\text { computing }\end{array}$ & Bangladesh & $\begin{array}{l}\text { Higher } \\
\text { education }\end{array}$ & $\begin{array}{l}\text { It Identified the factors that will influence } \\
\text { cloud computing adoption in } \\
\text { University of Dhaka of Bangladesh }\end{array}$ & $\begin{array}{l}\text { The scope of the study is } \\
\text { limited only at the University } \\
\text { of Dhaka }\end{array}$ \\
\hline $\begin{array}{l}\text { Başaran and } \\
\text { Hama [21] }\end{array}$ & $\begin{array}{l}\text { Cloud } \\
\text { computing }\end{array}$ & Turkey, Iraq & $\begin{array}{l}\text { Higher } \\
\text { education }\end{array}$ & $\begin{array}{l}\text { It offered education-specific solutions to } \\
\text { institutions regarding cloud computing } \\
\text { adoption }\end{array}$ & $\begin{array}{l}\text { They did not take into } \\
\text { consideration the information } \\
\text { security aspects }\end{array}$ \\
\hline
\end{tabular}

VCL: Virtual computing laboratory 
TABLE 2 : The most common readiness factors that have been used in the field of cloud computing service in higher education.

Readiness factors

\begin{tabular}{|c|c|c|c|c|c|c|}
\hline Fac. & Technological & HR & Cost & Educational & Info. security & Cultural \\
\hline \multicolumn{7}{|l|}{ Ref. } \\
\hline [11] & $\checkmark$ & $\mathrm{x}$ & $\checkmark$ & $\checkmark$ & $\checkmark$ & $\mathrm{x}$ \\
\hline [12] & $\checkmark$ & $\checkmark$ & $\checkmark$ & $\checkmark$ & $\checkmark$ & $\mathrm{x}$ \\
\hline [13] & $\checkmark$ & $\checkmark$ & $\checkmark$ & $\checkmark$ & $\checkmark$ & $\checkmark$ \\
\hline [14] & $\checkmark$ & $\checkmark$ & $\checkmark$ & $\mathrm{x}$ & $\checkmark$ & $\checkmark$ \\
\hline [15] & $\checkmark$ & $\checkmark$ & $\checkmark$ & $\mathrm{x}$ & $\checkmark$ & $\mathrm{x}$ \\
\hline [22] & $\checkmark$ & $\checkmark$ & $\mathrm{x}$ & $\mathrm{x}$ & $\checkmark$ & $\mathrm{x}$ \\
\hline [16] & $\checkmark$ & $\checkmark$ & $\checkmark$ & $\mathrm{x}$ & $\mathrm{x}$ & $\mathrm{x}$ \\
\hline [17] & $\checkmark$ & $\checkmark$ & $\checkmark$ & $\checkmark$ & $\mathrm{x}$ & $\checkmark$ \\
\hline [18] & $\checkmark$ & $\checkmark$ & $\checkmark$ & $\mathrm{x}$ & $\checkmark$ & $\mathrm{x}$ \\
\hline [19] & $\checkmark$ & $\checkmark$ & $\checkmark$ & $\mathrm{x}$ & $\checkmark$ & $\mathrm{x}$ \\
\hline [20] & $\checkmark$ & $\checkmark$ & $\mathrm{x}$ & $\mathrm{x}$ & $\checkmark$ & $\checkmark$ \\
\hline [21] & $\checkmark$ & $\checkmark$ & $\mathrm{x}$ & $\mathrm{x}$ & $\mathrm{x}$ & $\checkmark$ \\
\hline
\end{tabular}

\section{AN OVERVIEW OF CC AND ITS APPLICATION IN HE}

In this section, an overview of $\mathrm{CC}$ and it is an application in HEs is given. Furthermore, it is consisting of four parts, which are CC definition, the benefits of CC, the applying of $\mathrm{CC}$ service in education, and the employing of CC service in HE, as shown in Fig. 2.

\subsection{Definition}

There are a set of important definitions and reviews on CC. The which is the National Institute of Standards and Technology defined the CC as a model which enables handy, a network access when required to a shared pool of configurable computing resources, for example, networks, servers, storage, applications, and services that can be swiftly provisioned and released with the minimum effort of management or service provider interaction [11]. On a more elementary level, CC can be a systematic way for managing a set of virtual computers somewhere automatically and control them in such a simple way to create, manage, or even destroy over the network, without human action [12].

There are various security types within the CC technique, which can include networks, databases, operating systems, resource scheduling, virtualization, transaction management, concurrency control, and memory management [4]. Hashim et al. [13] referred that the key benefits of the CC are the ability to allow users to access data and software anywhere whenever there is internet service available and the ability to smooth sharing of learning materials and data, while the concerns about the security and data privacy can be considered as the main obstacle in this field.

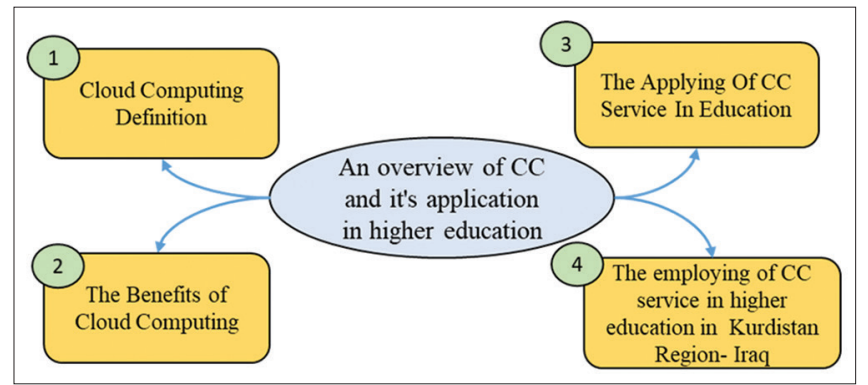

Fig. 2. An overview of cloud computing and its application in higher education.

The CC provides many types of services and when there is a full understanding of these services, it will be clear what this approach is all about. The main types of cloud services can be illustrated below:

- What is so-called Infrastructure as a Service (IaaS): Services provided by this level include the remote delivery (through the internet) of a full computer infrastructure (e.g., virtual computers, networks, and storage devices) [14]. The perfect example of this kind of service is Amazon1 which offers S3 for storage, EC2 for computing power, and simple queue service for network communication for limited businesses and individual consumers [23], just such as computer server and processing power [22].

- Platform as a Service (PaaS) which is PaaS: In this field, $\mathrm{PaaS}$ offered the ability to provide a software application without the need to install the software tool in consumer computers. The cloud development environment is the CC main access tool and their examples are operating systems, software testing tools [22].

- The other layer within these services is SaaS and under this layer, applications are delivered through 
the medium of the internet as a service. This type of service is running on the provider's infrastructures and is accessed through the client's browser (e.g., Google Apps and Salesforce.com) [6]. To use the required software, it can be simply accessed through the internet and this action can nominate the need to install the software itself. The complete functionality of the applications is embedded within this type of cloud service and these functionalities are a variety from the productivity such as (office-type) applications to programs just like those for the management of enterprise-resource or which refers to Customer Relationship Management, for example, Billing Software, Image, and Video editor [22], [23]. Moreover, Fig. 3 shows the types of CC service.

\subsection{The Benefits of CC}

In fact, there are multi benefits or advantages for the solutions provided by CC. Some of these benefits over traditional technologies are illustrated below:

- Mobility: In general, the current orientation is to increase the dependency on the facilities provided by mobile devices. In the HE field, the students harnessed the mobile devices' facilities to access data whether these data were a textbook, researches, syllabi, or even have the privilege to do their own homework. The applications within the cloud-based classroom can be considered as the most efficient way to make the exchange between student and faculty easier [7].

- New Services: The cost of traveling (for the international students), as well as other difficulties related to attendance in the classrooms, motivate the need for starting virtual classrooms through online learning and video conferencing which is provided nowadays by many colleges and universities. The

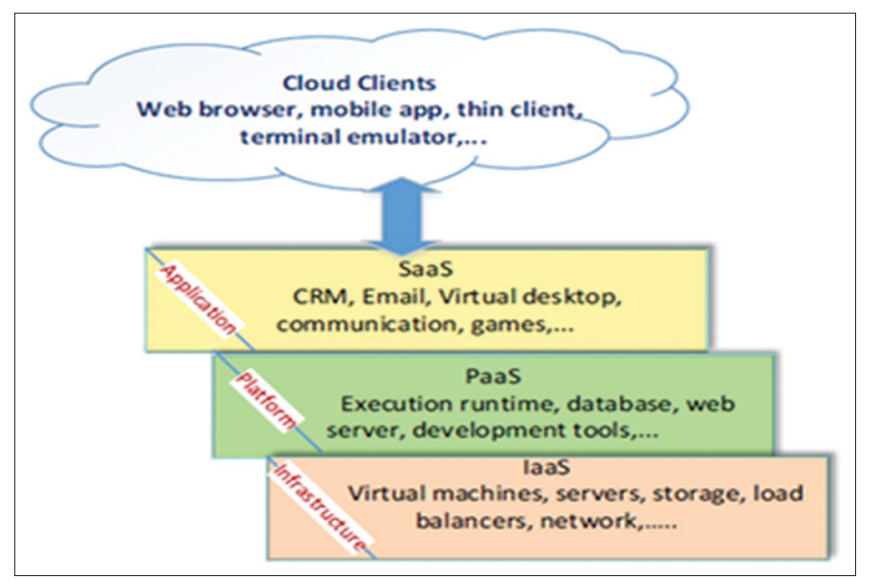

Fig. 3. Service models of cloud computing [22]. universities which offer the facilities to enable the students to join the classrooms from anywhere around the world using their own mobiles, computers, or tablets; could not provide such a service without the cloud servers [18].

- Storage: The actual usage of the CC by the universities provides them with the ability to quickly expand storage capabilities through scalable cloud storage. The data related to students are huge, starting from their own information, their marks, their medical records, and any other data. Here, the core risks are the chance to have a situation where these data can overwhelm traditional storage or even lost. The scalable cloud storage property alongside with business continuity and disaster recovery can be used to avoid such situations [9].

- Efficiency: In HE, there is always a striving by the universities to improve their organizations. Almost 55\% of the higher learning institutions looking forward to increase the efficiency and they trust in CC as the best way to achieve this goal [5].

Like everything in this life, there is advantages and benefits while in the other side there is risks and limitation and the CC is not an exception (Table 3 shows these risks and limitations), multiple cloud CC can the HE institutes choose but they have to take in their considerations the real need and the institute strategy itself [24].

\subsection{The Applying of CC Service in Education}

A rudimentary understanding of information and communications technology in the education field is one of the motivations and key factors for what can be seen as fast-changing technology. It is a necessary issue for HE actors to have a full understanding of how the cloud CC is adopted as well as involved. To transform the HE systems to be cloud-based systems, knowledge use and creation are a critical factor to ensure the full social, economic, and cultural transformation [24].

Coping with rapidly changing software and hardware needs at a lower cost in HE motivates many researchers to migrate from the classical systems toward the CC technique. The HE corporations planning to use $20 \%$ of the information techniques budget allocated for them, this will be done by shifting their applications toward the cloud. The challenges that would face this transition should be addressed within inclusive CC strategy; on the other hand, this step will ensure a smooth transition as well as optimal results to increase the institute's organizational efficiency [5]. 
TABLE 3 : The benefits and limitations of applying cloud computing in higher educations [24].

\begin{tabular}{|c|c|}
\hline Benefits & Limitations \\
\hline $\begin{array}{l}\text { It is available anywhere and } \\
\text { anytime }\end{array}$ & $\begin{array}{l}\text { Not all applications run in the } \\
\text { cloud }\end{array}$ \\
\hline $\begin{array}{l}\text { Support for teaching and } \\
\text { learning }\end{array}$ & $\begin{array}{l}\text { Data protection and security } \\
\text { issues }\end{array}$ \\
\hline $\begin{array}{l}\text { Low cost, since it is free or pay } \\
\text { depend on the use }\end{array}$ & Organizational support \\
\hline $\begin{array}{l}\text { Opening to the business } \\
\text { environment and advanced } \\
\text { research }\end{array}$ & $\begin{array}{l}\text { Dissemination politics, } \\
\text { intellectual property }\end{array}$ \\
\hline $\begin{array}{l}\text { Using green technologies to } \\
\text { protect the environment }\end{array}$ & Maturity of solutions \\
\hline $\begin{array}{l}\text { Increased openness of students } \\
\text { to new technologies }\end{array}$ & Lack of confidence \\
\hline $\begin{array}{l}\text { Increasing functional } \\
\text { capabilities }\end{array}$ & Standards adherence \\
\hline $\begin{array}{l}\text { Offline usage with further } \\
\text { synchronization opportunities }\end{array}$ & $\begin{array}{l}\text { Speed/lack of internet can affect } \\
\text { work methods }\end{array}$ \\
\hline
\end{tabular}

In $\mathrm{HE}$, it is obvious that the main beneficiaries are students and all faculty staff (academic and administrative). These users have access to the data alongside the control on those data through the internet. The privileges and activities to all the users who connected to the cloud are a variety from uploading lectures, assignments, and tests (for teachers) as well as accessing those lectures, assignments, and tests (for students) re-upload the assignments and test if necessary. The main requirement to access the cloud anywhere and anytime is the availability of internet service [12], [25]-[27].

However, what so-called "the intelligent education" or the "Electronic education" can get its entire requirement to be efficient like the application software itself as well as the required database alongside with email management from the SaaS. On the other hand, the shortage or the breakdown here is concentrated in the dependence of this technique on the internet. Since that, the internet is a key factor for the permanence of the CC; all the HE users (staff and students) have to ensure the continuity of the internet service as well as ensuring that the internet connection is fast enough to have the full access to the cloud services at any time [28].

Moreover, in the work of Al-Khayat and Al-Othman [29] tried to make the design of the educational CC comprehensive and complete. The proposed generic CC model is to implement many frameworks for improving the quality of education of students and academic staff besides saving time. Although the using of modern ICT are the cornerstone of modern teaching and learning in the engineering colleges and institutes in Iraq, the extensive use of educational technologies and investing time and efforts in buying and maintaining infrastructure was disrupting the aim of establishing effective teaching and learning environment. To face this big problem and to an emphasis on quality of education, there should be an awareness about the CC benefits on cost-effectively providing better education services in addition to making a real investment of CC in providing both SaaS and infrastructure [29].

The CC resources can be accessed whenever required and with the minimum effort needed for managing these resources. The goal of applying the CC on HE is differing from one country to another and from one region within the world to another. In Africa, the main goal is establishing systems that can provide students with services like e-library. From the perspective of the organizations themselves, the goal can be summarized in reducing the cost and improve their IT capabilities. At the same time, fear and uncertainty still exist from applying the CC in the HE system. Taking into consideration the risks and struggles in adopting the $\mathrm{CC}$ in the HE system in Africa and comparing them to the benefits, the applying of CC is inevitable [13].

The education system will make it possible for teachers to highlight the weakness areas where the students used to make mistakes, this activity can be done through the students' records analyzing. This analysis will enable teachers to improve or even change their teaching methods. Applying this technique will allow the students to have access to the lectures during the classes or even at home. Sharing learning materials and hardware (servers) by all the university colleges will reduce the operation cost for the universities effectively through the Utilization of cloud CC systems [30]. Furthermore, Fig. 4 shows the users as well as the way that these users interact with the CC.

\subsection{The Employing of CC Service in HE in the Kurdistan Region - Iraq}

The strategy of clouds must be related to the strategy of various academic institutions or universities. The transformation to CC- based establishments requires full knowledge about how it can function in different aspects and principles associated with organizational structure and relations between universities and institutions alongside with advantages and risks, security issues, and policies. Recently, the cloud CC researches illustrated the best usage practices of CC contain the following phases [31], [32].

- Evaluating the current level of the various institutions from the perspective of the IT requirements, framework, 


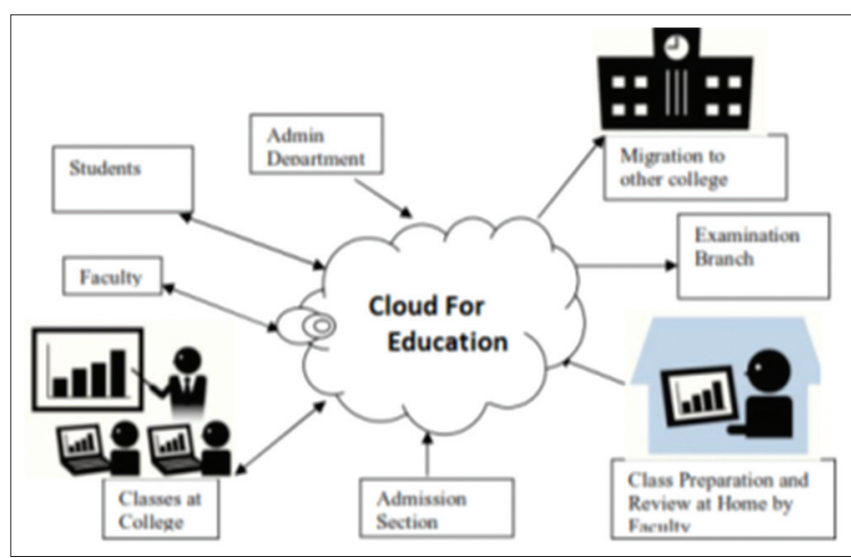

Fig. 4. Cloud computing service application in higher education's [30].

and usage: This step includes the understanding of various institutions' IT structure.

- Experimenting with the CC solutions: The applications and projects cannot be transformed to be cloud-based applications or projects suddenly, this shifting has to be step by step starting from experimenting with the CC technique on the pilot application and then apply it on other chosen applications. To do so, setting cloud goals just such as development and testing the environment or storing some data within the cloud and continue processing the internal processes is required [33], [34].

- Selecting the CC solution: Within this step, determining the data and applications, structure, functions, and core processes within the academic institutions is done. They may be grouped according to teaching, research, and administrative support. It also contains the cloud model which has been chosen (private, public, community, and hybrid) for the specified processes, functions, and applications [35], [36]. However, Table 4 shows the CC types.

\subsection{Brief History of HE in Kurdistan}

Kurdistan is a federal state located in the north of Iraq that has its own law and legislation, with a populace of 5.2 million and expanding the three governorates of Erbil, Slemani, and Duhok, cover roughly $40,000 \mathrm{~km}^{2}$ [37]. KRG has realized how HE is important to upgrade the federal state infrastructure. KRG starts allocating a big portion slightly from its budget for the education field in general and $\mathrm{HE}$ in specific, just like in the 2013 budget where 16\% of the budget was allocated to this issue [38]. Although, there was only one university in Kurdistan until 1992; in general, highly valued and has a special space in society. Gradually, the KRG policy has adopted huge investment in the H.E field which results in opening new HE institutes [39]. Kurdistan Region oversees 33 universities.
TABLE 4: Cloud computing types [43].

\begin{tabular}{ll} 
Type & Description \\
\hline Public cloud & $\begin{array}{l}\text { Services provided by organizations and } \\
\text { customers pay for what they actually use, in } \\
\text { terms of being cost-effective, public cloud is } \\
\text { considered superior over the other, on the } \\
\text { other hand, it raises other issues such as } \\
\text { security, privacy, and levels of controls } \\
\text { Services provided to and managed by the } \\
\text { organizations' staff themselves or any third } \\
\text { party vendors, this cloud service is not } \\
\text { provided to the general public, the private } \\
\text { cloud could be implemented locally or remotely }\end{array}$ \\
Type of cloud provided to a specific target \\
Group of people, the services are shard \\
Hybrid cloud & $\begin{array}{l}\text { exclusively among the members of this group } \\
\text { only } \\
\text { Combination of two or more cloud - the private } \\
\text { clouds, public cloud, and the community }\end{array}$ \\
\hline
\end{tabular}

These include 14 public and 15 state-recognized private universities, two universities with different ownership and two institutions [40], [41].

Some universities provide virtual computing labs which can be considered as a virtual environment where the students have the ability to reserves PCs [42]. The reserved PCs have their own specialized hardware as well as software. This environment enables the students when they have an internet service; to access those reserved computers from anywhere. Therefore, within the suggested technique, IaaS provides virtual machines (VMs) when they are needed for students of the university. The main reason for using these VMs is divided into two parts; the first one is to make courses and lab exercises. The other sub-reason is to build virtual labs. However, the advantages of using such an environment can be summarized in the ability of users (students and university staff) to use the resources. On the other hand, economic incomes can be achieved for the university. The work of Hashim et al. [12] showed that Bayan University achieved the task of using the system of cloud education through the technology of virtualization which illustrated the main point of virtual computing laboratory. This system allows the university to provide a flexible environment for their students to have access to the computers available within the university labs as well as reducing jams of using the computer hardware.

A new step in developing HE in Iraq has done when the MHE in Kurdistan applied an online registration system which enabled the students all over the republic of Iraq to select their universities and colleges. This action and many other effective steps done by the KGR, raise the number of 
the HE students to 94,700 according to latest statistics $48 \%$. Of this number are female students. The academic degrees offered by the universities within the Kurdistan Region are diploma (2 years), bachelor (4 years), master ( 2 years), and doctorate (Ph.D.) (3-5 years) in multiple scientific and administrative academic fields and others [44].

The educational system in Kurdistan can be considered as an unstructured system; alongside using, the technologies are real problems to the MHE of Kurdistan. A survey has been conducted to determine using the extent of CC in KR universities; the questions within the survey (which included 222 academic staff and students from 14 universities) were varying to cover the requirements needed to apply the CC in their universities. The researchers in Ahmed et al. [3] highlights the main reasons to use the CC within the KR universities just such as reducing the cost, enhancing the university structure, develop the performance, and other related issues. On the other hand, the researchers illustrated the drawback and challenges confront applying the CC in KR just like lack of ICT infrastructure, security issues, privacy, and shortage of current systems, and data and documents ownership. To reduce the drawbacks of public cloud and get the advantages of CC HEIs and universities in KRG have to change their strategies from using public clouds to use their owned clouds [3].

\section{CONCLUSION}

The applying of CC in HE is providing many advantages such as steady, rapid, sample, suitability, and simultaneous accessibility of belongings at low cost in comparison with other techniques through the internet to the users. In this study, the existence of CC adoption frameworks for universities in developing countries along with Iraq has been discussed briefly. A review of these studies showed that the university within Kurdistan Region in Iraq needs continued attention to get government support, CC within Iraqi HE universities has limited developed over the latest years in the private and public universities. The findings indicate that interventions designed to increase the CC adoption need to include a focus on the practice level because that is decisionmaking regarding adoption occurs, in addition, to help IT, managers, within institutions to change their workflow to obtain the most services, along with addressing privacy concerns and explicitly acknowledging.

In addition, the study offered a variety of university settings to ensure higher generalizability associated with the outcomes.
All these results can be mainly relevant and timely concerning the decision maker who presently faces the obstacle of CC adoption in the Iraqi education environment. The limitations of this study include that there was single-source bias, as the collection of information was from secondary sources only. Furthermore, the study has more of a judgmental conclusion, as there is no post data assessment. HE universities should figure out how to rationalize their students' needs and priorities, applications, and their own premise information, and after that merge their framework accordingly. Finally, the most related work to this study has discussed to attempt to fill a gap in the current research to develop an adoption model that can help Iraqi HE universities to adopt CC. Therefore, it is recommended for future researchers to conduct a field survey by collecting primary data and conducting statistical tests on the variables implicated in the findings of this study. Furthermore, due to the bold role of the internet and cyberspace in human life and its impact on behavior, lifestyle, it is suggested in future works monitor the role of social media in the use of CC in education.

\section{REFERENCES}

[1] A. H. Masud, X. Huang and J. Yong. "Cloud Computing for Higher Education: A Roadmap". In: 2020: International Conference on Computer Supported Cooperative Work in Design, pp. 552-557, 2012.

[2] Z. A. Ahmed and M. I. Ghareb. "An online course selection system: A proposed system for higher education in Kurdistan region government". International Journal of Scientific and Technology Research, vol. 7, no. 8, pp. 145-160, 2018.

[3] Z. A. Ahmed, A. A. Jaafar and M. I. Ghareb. "The ability of implementing cloud computing in higher education-KRG". Kurdistan Journal of Applied Research, vol. 2, pp. 39-44, 2017.

[4] Q. K. Kadhim, R. Yusof, H. S. Mahdi, S. S. Al-shami and S. R. Selamat. "A review study on cloud computing issues". Journal of Physics: Conference Series, vol. 2018, p. 12006, 2018.

[5] V. H. Pardeshi. "Cloud computing for higher education institutes: Architecture, strategy and recommendations for effective adaptation". Procedia Economics and Finance, vol. 11, pp. 589599, 2014.

[6] M. T. Amron, R. Ibrahim and S. Chuprat. "A review on cloud computing acceptance factors". Procedia Computer Science, vol. 124, pp. 639-646, 2017.

[7] M. N. Qadri and S. Quadri. "A study of mapping educational institute with cloud computing". International Journal of Scientific Research in Computer Science, Engineering and Information Technology, vol. 2. pp. 59-66, 2017.

[8] M. Al Rawajbeh, I. Al Hadid, J. Aqaba and H. Al-Zoubi. "Adoption of cloud computing in higher education sector: An overview". Indian Journal of Science and Technology, vol. 5, no. 1, pp. 23-29, 2019.

[9] K. H. Al-Shqeerat, F. M. Al-Shrouf and H. Fajraoui. "Cloud computing security challenges in higher educational institutions-a survey". International Journal of Computer Applications, vol. 161, pp. 22-299, 2017. 
[10] U. Singh and P. K. Baheti. "Role and service of cloud computing for higher education system". International Research Journal of Engineering and Technology, vol. 9, p. 10, 2017.

[11] T. A. Kadhim. "Development a teaching methods using a cloud computing technology in Iraqi schools". Journal of University of Babylon, vol. 26, pp. 18-26, 2018.

[12] E. W. A. Hashim, M. O. Hammood and M. T. I. Al-azraqe. "A Cloud Computing System Based Laborites' Learning Universities: Case Study of Bayan University's Laborites-Erbil'. Book of Proceeding, p. 538, 2016.

[13] A. S. Abdusalam, D. Faiq Abd, Z. A. Hamid, Z. A. Kakarash and O. H. Ahmed. "Study of challenges and possibilities of building and efficient infrastructure for Kurdistan Region of Iraq". UHD Journal of Science and Technology, vol. 2, pp. 15-20, 2018.

[14] M. Al-Hashimi, M. Shakir, M. Hammood and A. Eldow. "Address the challenges of implementing electronic document system in Iraq e-government-Tikrit city as a case study". Journal of Theoretical and Applied Information Technology, vol. 95, pp. 3672-3683, 2017.

[15] H. Abdulkadhim, M. Bahari, H. Hashim and A. Bakri. "Prioritizing implementation factors of electronic document management system (EDMS) using topsis method: A case study in Iraqi government organizations". Journal of Theoretical and Applied Information Technology, vol. 88, pp. 375-378, 2016

[16] T. H. Thabit and S. A. Harjan. "Evaluate e-learning in Iraq applying on Avicenna center in Erbil”. European Scientific Journal, vol. 11, pp. 1-14, 2015.

[17] S. Riaz and J. Muhammad. "An evaluation of public cloud adoption for higher education: A case study from Pakistan". In: Mathematical Sciences and Computing Research (iSMSC), International Symposium, pp. 208-213, 2015.

[18] M. W. Nofan and A. A. Sakran. "The usage of cloud computing in education". Iraqi Journal for Computers and Informatics, vol. 42, pp. 68-73, 2016.

[19] K. C. Ariwa and E. Aiwa. "Engineering sustainability and cloud computing in higher education-a case study model in Nigeria". International Journal of Computing and Network Technology, vol. 5, pp. 65-75, 2017.

[20] J. Sultana, N. Nipa, and F. A. Mazmum. "Factors affecting could computing adoption in higher education in Bangladesh: A case of university of Dhaka". Applied and Computational Mathematics, vol. 6, pp. 129-136, 2017.

[21] S. Başaran and G. O. Hama. "Exploring Faculty Members Views on Adoption of Cloud Computing in Education. In: Proceedings of the International Scientific Conference. vol. 5, p. 237, 2018.

[22] Z. Asadi, M, Abdekhoda and H. Nadrian. Cloud computing services adoption among higher education faculties: Development of a standardized questionnaire. Education and Information Technologies, vol. 25, no. 1. pp. 175-191, 2020.

[23] P. R. Maskare and S. R. Sulke. "Review paper on e-learning using cloud computing". International Journal of Computer Science and Mobile Computing, vol. 3, pp. 1281-1287, 2014.

[24] M. M. Seke. "Higher education and the adoption of cloud computing technology in Africa." International Journal on Communications, vol. 4, p. 1, 2015.

[25] M. S. Abdullah and M. Toycan. "Analysis of the factors for the successful e-learning services adoption from education providers' and students' perspectives: A case study of private universities in Northern Iraq". Eurasia Journal of Mathematics, Science and Technology Education, vol. 14, pp. 1097-1109, 2017.

[26] N. Sultan. "Cloud computing for education: A new dawn"?
International Journal of Information Management, vol. 30, pp. 109116, 2010.

[27] H. S. Hashim, K. Conboy and L. Morgan. "Factors influence the adoption of cloud computing: A comprehensive review". International Journal of Education and Research, vol. 3, pp. 295306, 2015

[28] A. O. Akande and J. P. Van Belle. "Cloud Computing in Higher Education: A Snapshot of Software as a Service". In: Adaptive Science and Technology, IEEE $6^{\text {th }}$ International Conference, pp. 1-5, 2014.

[29] M. S. Al-Khayat and M. S. Al-Othman. "A proposed cloud computing model for Iraqi's engineering colleges and institutes". ZANCO Journal of Pure and Applied Sciences, vol. 28, pp. 1-5, 2016.

[30] P. Darus, R. B. Rasli and N. Z. Gaminan. "A review on cloud computing implementation in higher educational institutions". International Journal of Scientific Engineering and Applied Science, vol. 1, pp. 459-465, 2015.

[31] A. Barnwal, D. Kumar. "Using cloud computing technology to improve education system". Asian Journal of Technology and Management Research, vol. 4, pp. 68-72, 2014.

[32] D. F. Fithri, A. P. Utomo, and F. Nugraha. "Implementation of SaaS cloud computing services on E-learning applications (case study: PGRI foundation school)". Journal of Physics: Conference Series, vol. 1430, no. 1, p. 012049.

[33] T. Bozzelli. "Will the Public Sector Cloud Deliver Value? Powering the Cloud Infrastructure". Available from: http://www.cisco.com/ web/strategy/docs/gov/2009_cloud_public_sector_tbozelli.pdf. [Last accessed on 2010 Oct 05].

[34] K. Njenga, L. Garg, A. K. Bhardwaj, V. Prakash and S. Bawa. "The cloud computing adoption in higher learning institutions in Kenya: Hindering factors and recommendations for the way forward". Telematics and Informatics, vol. 38, pp. 225-246, 2019.

[35] I. Arpaci. "A hybrid modeling approach for predicting the educational use of mobile cloud computing services in higher education". Computers in Human Behavior, vol. 90, pp. 181-187, 2019.

[36] M. R. Mesbahi, A. M. Rahmani and M. Hosseinzadeh. "Reliability and high availability in cloud computing environments: A reference roadmap". Human-Centric Computing and Information Sciences, vol. 8, no. 1, pp. 20, 2018.

[37] A. A. Jaffar, M. I. Ghareb and K. F. Sharif. "The challenges of implementing E-commerce in Kurdistan of Iraq". Journal of University of Human Development, vol. 2, 2016.

[38] R. Avci and N. Doghonadze. "The challenges of teaching EFL listeningin Iraqi (Kurdistan Region) Universities". Universal Journal of Educational Research, vol. 5, pp. 1995-2004, 2017.

[39] D. S. Atrushi and S. Woodfield. "The quality of higher education in the Kurdistan Region of Iraq". British Journal of Middle Eastern Studies, vol. 14, pp. 11-16, 2018.

[40] N. Ahmed. "Performance Appraisal in Higher Education Institutions in the Kurdistan region: The case of the University of Sulaimani". Cardiff Metropolitan University, Wales, 2016.

[41] S. Razzaghzadeh, A. H. Navin, A. M. Rahmani and Hosseinzadeh, M. "Probabilistic modeling to achieve load balancing in expert clouds". Ad Hoc Networks, vol. 59, pp. 12-23, 2017.

[42] H. P. Breivold and I. Crnkovic. "Cloud Computing education strategies". In: IEEE 27 ${ }^{\text {th }}$ Conference Software Engineering Education and Training, pp. 29-38, 2014.

[43] M. A. Wahsh and J. Dhillon. "A systematic review of factors affecting the adoption of cloud computing for E-government 
Abbas M. Ahmed and Osamah Waleed Allawi: The Possibility of CC Application in Higher Education of Northern Iraq

implementation". Journal of Engineering and Applied Sciences, ARPN Journal of Engineering and Applied Sciences, vol. 23, pp. 17824-17832, 2015.

[44] J. F. Kakbra and H. M. Sidqi. "Measuring the impact of ICT and e-learning on higher education system with redesigning and adapting MOODLE system in Kurdistan Region Government, KRGIraq". In: Proceedings of the $2^{\text {nd }}$ e-learning Regional Conference State of Kuwait, p. 13, 2013. 